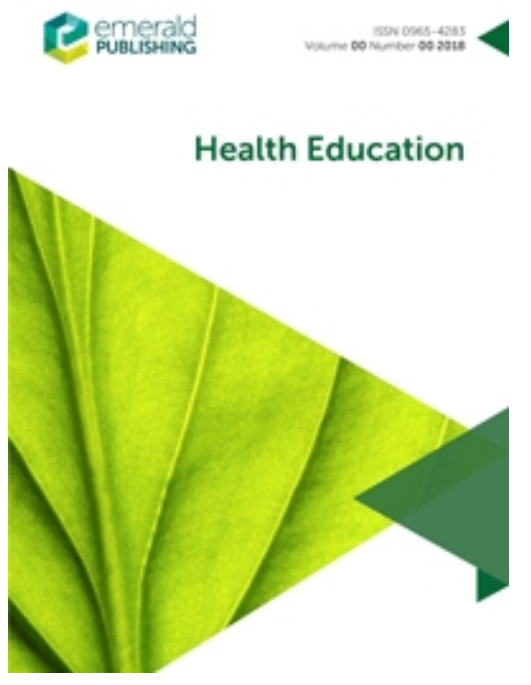

\title{
Engaging students in experiential learning through a public health campaign: a pre-post survey on hypertension and diabetes mellitus
}

\begin{tabular}{|r|l|}
\hline Journal: & Health Education \\
\hline Manuscript ID & HE-05-2021-0082.R1 \\
\hline Manuscript Type: & Original Article \\
\hline Keywords: & $\begin{array}{l}\text { Public Health, Learning styles, Health promotion, curriculum } \\
\text { development }\end{array}$ \\
\hline \multicolumn{2}{|l}{} \\
\hline
\end{tabular}

\section{SCHOLARONE ${ }^{\text {Im }}$ \\ Manuscripts}




\title{
Engaging students in experiential learning through a public health campaign: a pre-post survey on hypertension and diabetes mellitus
}

\begin{abstract}
Purpose - This study looked at the impact of a community-based public health campaign on hypertension and diabetes mellitus awareness and prevention, as well as student experiential learning in a campaign conducted by pharmacy students.
\end{abstract}

Design/ methodology/ approach - A convenience sampling cross-sectional pre-post survey was done to assess disease awareness and knowledge among those who attended the health campaign. The data analysis includes a total of 230 participants with complete data. After the campaign, the pharmacy students used self-assessment to reflect their learning experience.

Findings - Most participants were unaware of their blood pressure and blood glucose readings, but they reported improved awareness of diseases and prevention of hypertension and diabetes after the health campaign. Although most participants correctly identified the common signs and symptoms of hypertension, few could associate it with overweight. Most participants were unaware of the $5 \mathrm{~g}$ per day salt intake limit for controlling hypertension before the campaign. Most participants were less aware that diabetes is associated with impaired vision, peripheral neuropathy, renal and heart diseases. Students expressed increased confidence in leadership, teamwork, and communication abilities after the campaign, based on self-assessment.

Research implications - A health campaign enhances the disease knowledge of the general public. It has been suggested that experiential learning be encouraged in the pharmacy curriculum.

Originality/value - This study adds to the knowledge on the roles of community-based health campaigns and the value of pharmacy students involvement in experiential learning.

Keywords: public health, disease awareness, health promotion, experiential learning, pharmacy curriculum

Paper type: Research paper 


\section{Introduction}

Hypertension and hyperglycemia, left untreated, can greatly increase the risk of serious life-threatening complications. Due to the nature of these diseases, the signs and symptoms often do not manifest until a later stage; hence, the term "silent killers".

According to the Malaysian National Health and Morbidity Survey, the prevalence of hypertension and diabetes mellitus was $30 \%$ and $18.3 \%$, respectively (Institute for Public Health, 2019). Some $14.1 \%$ of the patients with newly diagnosed hypertension were reported to be unaware of their hypertension, whereas $8.9 \%$ of the newly diagnosed patients with diabetes mellitus were unaware of their condition before the diagnosis. Both cardiovascular diseases and diabetes mellitus are major contributors to the total disease burden in Malaysia (Ministry of Health, 2004), highlighting the seriousness of hypertension and diabetes mellitus in the Malaysian population.

People in the community need to be aware of their health status to monitor and control their blood pressure and blood sugar levels. Various interventions could be used to disseminate health information to the general public. Face-to-face consultations, the use of mass media, and healthpromotion programs are the primary modalities for disseminating public health information (Health Development Agency, 2004). A community-based health campaign promotes public health within communities, often with a time-specific scope of interest. It focuses on direct education to the community and disease prevention strategies by mobilizing the communities' citizens (Kibler et al., 2018; Landy et al., 2013) These education and awareness programs are frequently conducted by health professionals, and in some cases, by advocates in the community or by patients affected by the diseases.

Pharmacy is a part of the health care system contributing to patient-centred care and optimal drug therapy outcomes. The pharmacy profession has long been recognised for its roles in public health, health promotion and disease prevention (Levin et al., 2018; Strand et al., 2020). Pharmacists' responsibilities have grown in recent decades such as self-care, herbal supplement management, and even COVID-19 vaccination administration. (Bell et al., 2016; Petrelli et al., 2019; Yeong and Choong, 2017). Pharmacists' expanding roles in public health necessitate changes in pharmacy education and training. 


\section{Aims and objectives}

The aim of this study was to evaluate how a community-based public health campaign improved illness awareness and prevention, as well as how much experiential learning aided pharmacy students' learning. There are two specific objectives, which include:

(a) investigating whether community-based health campaigns contribute to the increased public awareness of disease knowledge and prevention of hypertension and type 2 diabetes mellitus.

(b) employing a self-assessment questionnaire to assess pharmacy students' experience learning in planning a community-based health campaign.

\section{Methods}

This study looks at the outcomes of a community-based campaign and reports the experiential learning of a group of pharmacy students.

\section{Pre-post survey of participants}

The study design of this research engages the use of cross-sectional, pre-post surveys in the form of self-administered questionnaires at a community-based health campaign site to understand the outcomes of the health promotion campaign. The survey instrument was developed with reference to other cross-sectional studies on disease awareness and prevention (Fryar et al., 2017; Ministry of 
Health, 2004; Ministry of Health Malaysia, 2018; National Institute of Health, 2017). Questionnaires were developed with the 3 main languages used among the communities' various ethnic groups, including English, Malay, and Chinese. Both content and translation validation were conducted (Cota et al., 2017)' (Zamanzadeh et al., 2015). Translation validation was performed for the questionnaires in 3 different languages. Forward and backward translations were performed; the translated version was compared with the original version of the questionnaire based on conceptual and cultural equivalence. Five academic staff proficient in their mother tongue (in each of the languages) and English provided consultation in the content and translation validation. The questionnaires were amended based on them before the pilot study.

A pilot study was conducted with 5 participants for each language version (English, Bahasa Malaysia, and Mandarin) of the questionnaire. This pilot study aimed to ensure proper interpretation between the 3 language versions and to reduce oversights and bias in the questionnaires. Data from the pilot study were not included in the final data analysis.

Convenience sampling was used with participants recruited from the site of the communitybased public health campaign. Participants were recruited according to the following inclusion and exclusion criteria. Inclusion criteria included participants aged 18 years and older, with the understanding of 1 of the following 3 languages: English, Malay, or Chinese. Exclusion criteria included those not registered in the community-based health campaign and those who did not provide consent to participate. The questionnaires were administered after obtaining written consent from the participants.

Upon completing the pre-campaign questionnaire, participants began the community-based health campaign activities, including health screenings and attending a poster exhibition about diseases and prevention. Poster exhibitions with general information about hypertension and type 2 diabetes mellitus were displayed at the campaign site. Explanations about the general information on the posters were provided by pharmacists and trained pharmacy students. Random blood pressure and blood glucose measurements were taken at the campaign site. A post-campaign questionnaire was completed before participants exited the health campaign site. Registered pharmacists were at the site to answer enquiries from the public regarding medicines and diseases. They explained the random screening readings to the participants and advised them to seek further medical check-ups if needed. The pharmacist also explained other medicine-related matters. 
The sample size for this cross-sectional survey was calculated using the formula below (Charan and Biswas, 2013):

$$
\begin{aligned}
& \mathrm{n}=\quad\left(\mathrm{Z}_{1-\alpha / 2}\right)^{2} \mathrm{P}(1-\mathrm{P}) \\
& \mathrm{d}^{2}
\end{aligned}
$$

n: sample size

$\left(Z_{1-\alpha / 2}\right): 1.96$ with $95 \%$ confidence interval, when the $\mathrm{p}$-value is less than 0.05

$\mathrm{P}$ : expected prevalence or proportion in population-based on previous studies, which is 0.14

d: absolute error or precision

A minimum of 185 participants was needed for this study.

Data were coded, entered, and subjected to statistical analysis using Statistical Package for the Social Sciences (SPSS) software version 20. Descriptive data were expressed as frequency and percentage. Wilcoxon signed-rank test was used to compare variables between pre-post data in the survey.

\section{Experiential learning in organising a health campaign}

This community-based health campaign was organised by a group of pharmacy students with the support of registered pharmacists. For organising the health campaign, students receive extracurricular credit. Credits obtained count toward the number of credits necessary for graduation. Prior to the health campaign, students were expected to submit a proposal that included explanations of the campaign's themes and focus, targeted communities, health promotion strategies, activity budgets, and fundraising plans. The plan required approval from both the faculty and the university's student affairs division. The health campaign included disease awareness and prevention activities such as health information exhibitions, health screening tests, health discussions and forums, and drug counselling sessions. Students were asked to produce a post-event report that included a self-assessment to reflect on their experiential learning experience. 


\section{Results}

\section{Outcomes of a community-based health campaign}

A total of 220 participants who met the inclusion criteria and consented to participate were recruited.

Table 1 summarizes the demographics of the participants in this pre-post survey. There were more women than men in this study. The majority of the participants were younger than 50 years of age and were married.

The majority of the participants were not aware of their blood pressure and blood glucose readings before attending the health campaign event (refer to Table 1). Blood pressure measured at the campaign site revealed that $29.3 \%$ of the participants had high blood pressure and $5.5 \%$ of the participants had elevated blood glucose.

\section{[Place Table 1 here if possible\}}

Table 2 summarises the knowledge level of the participants in hypertension. The participants were found to be more knowledgeable about hypertension after the campaign compared with before, in relation to the questions asked. Fewer participants knew about the association between potassium intake and blood pressure pre-campaign compared with post-campaign. Although many were aware that high salt intake results in high blood pressure, not many knew about salt's daily maximum limit. Participants were also less aware that ageing and being overweight contributes to the risk of hypertension. Many of the participants were aware that hypertension could lead to heart failure and stroke; however, fewer of them associated kidney failure and impaired vision with hypertension.

Table 3 annotates the knowledge level of participants on diabetes. Participants showed significantly improved knowledge that thirst, hunger, and weight-loss were signs of type 2 diabetes mellitus after the campaign. Although participants showed sufficient knowledge about healthy lifestyles to prevent diabetes mellitus, many did not associate ageing and overweight as risk factors. Most of the participants knew that diabetic foot is a complication of diabetes; however, the majority did not associate peripheral neuropathy with diabetes.

\section{[Place Table 2 and Table 3 here if possible\}}




\section{Experiential learning reflections of pharmacy students}

This community-based health campaign was organised by a group of 40 pharmacy students from year 1 and year 2 under the supervision of academic staff and qualified pharmacists. The creation of an organising committee, consisting of a chairperson, a treasurer, and a secretary, was mentioned in the post-event report. Structured divisions were developed to carry out the various health promotion activities, such as producing display materials, organising health screening activities, acquiring sponsorships, engaging with the public, and publicizing the campaign among the community. Additionally, pharmacy students worked with community pharmacists, doctors, health organisations, and community associations in the area.

The students completed a self-assessment to critically reflect on the learning experience after the health campaign.

Their responses were as follow:

- 69 per cent "strongly agree" and 11 per cent "agree" that their participation in the health campaign helped them to better understand the knowledge learned in their didactic courses.

- 92 per cent reported that they used what they learnt to organise the health campaign.

When comparing the learning experience of the health campaign to formal didactic courses,

- 94 per cent indicated that they are better prepared for leadership and teamwork skills;

- 86 per cent believed that they are better prepared for project management and budgeting skills;

- 83 per cent indicated that they were better in presentation and interpersonal skills;

- 69 per cent believed that they better understand cultures and personal behaviour in health;

- 64 per cent indicated that they develop better critical and problem-solving skills.

\section{Discussion}

In this study, more women attended the campaign. The trend to have more women could be due to the greater health consciousness of women regarding self-care (Duplaga, 2019). Duplaga M et al. similarly reported more women in their study, and that men were more sceptical about the effectiveness of health-related campaigns. The screening tests of abnormal blood pressure readings among the participants in this study aligned to the prevalence of hypertension reported in the national level reported in NHMS 2019, whereas the number of abnormal high blood glucose levels was much lower. 
The lower number of abnormal blood glucose readings in our study could be due to the random blood glucose taken at the campaign and not the fasting blood glucose tests employed for the reporting of confirmed diabetes diagnosis at the national level. Nonetheless, these findings indicate further screening and diagnosis are needed at the community for chronic diseases such as diabetes and hypertension.

Naing et al. had reported that those younger than 40 years old were more willing to attend health screening tests (Naing et al., 2014). The results of our study concur with this report, with the majority of our participants aged younger than 50 years. Factors such as better access to the internet, faster access to health information, and better health education and awareness could have resulted in greater participation of the younger population in the health campaign. The fact that free health screening tests were available at the campaign could have been another aspect that drew younger people in. Those who have been diagnosed with the two disorders and see their doctors on a regular basis, usually older age groups, are less likely to attend the campaign as they believe their problems have been adequately addressed (Naing et al., 2014)

One of the concerning findings in this study was the low self-awareness of own health status of the participants. This finding concurred with similar studies, which have indicated a low level of health status self-awareness among Malaysians (Abdul-Razak et al., 2016a)' (Minhat and Hamedon, 2014)' (Yen et al., 2017). There is a need to review the success of mass communication in changing the health behaviours of individuals in the communities.

Several studies have reported that a lack of community understanding of the importance of health screenings was the most common barrier to the early detection of hypertension and diabetes mellitus (Kibler et al., 2018; Shima et al., 2014). In addition, poorer people and indigenous ethnic groups were said to be less aware of their health state and are less likely to be treated for their ailments (Abdul-Razak et al., 2016). Community-based health campaign targeting these populations could identify local health matters, identify high-risk individuals and share public health messages across the entire community to further support population health.

Overall, the participants were sufficiently aware of the signs and symptoms and healthy lifestyles for hypertension and diabetes. This may be due to the success of mass communication of health promotion messages. However, participants in this study did not recognise kidney failure and 
impaired vision as complications of hypertension. This finding is consistent with other studies in which the respondents were not able to identify the complications of hypertension (Bilal et al., 2015)' (Sathish Kumar et al., 2015). Although the participants in our study recognized kidney disease and diabetic foot as complications of diabetes mellitus, they were not able to associate peripheral neuropathy with diabetes mellitus. Despite being aware of physical inactivity as a risk factor, they did not associate overweight with diabetes mellitus. In addition, a study in Kuala Lumpur showed that $60 \%$ of the respondents had a misconception that diabetes mellitus is curable (Mahmud, 2015). Similar findings have been shown in other studies (Qamar et al., 2017)' (Deepa et al., 2014). Health education materials might require the use of appropriate examples relevant to the daily practice of a multi-ethnic group. Appropriately explained medical terms and information are also important for effective health promotion. Our campaign was able to identify the lack of knowledge or misconceptions of the local community about certain aspects of disease knowledge.

Our findings showed that this community-based health campaign could identify participants with abnormal blood pressure and blood glucose readings. Advice for further action by the participants was provided by health professionals. Landy et al. had reported the effectiveness of their campaign in identifying participants with abnormal blood cholesterol levels (Landy et al., 2013). Altman et al. had found that participants in a community-based campaign showed improved knowledge of the symptoms and risk factors of cardiovascular disease (Altman et al., 2014). Community-based health campaigns with knowledgeable health professionals could further educate the public and support healthier living styles.

The pharmacy students demonstrated their learning process, which began with prior learning experiences in didactic courses, progressed to concepts with a project proposal, then to new experiences with learning in a real - world setting, and finally to self-assessment and reflections on their learning; These are the components of Kolb's Experiential Learning Theory concrete experience abilities, reflective observation abilities, abstract conceptualisation abilities, and active experimentation abilities (Kolb and Kolb, 2017). Self-assessment in this study, on the other hand, was structured and connected to the needs of the university's extra-curriculum credit units, in contrast to Kolb's reflective observation abilities, which did not emphasise "critical" reflection. (Morris, 2020). Students did, however, gain additional skills necessary for their professional careers, which will help them continue to learn and practise in a field with ever- 
expanding positions in public health. (Sinclair et al., 2020; Singh et al., 2020; Smith and Olin, 2010).

\section{Conclusion}

This study shows that a community-based health campaign supports disease awareness and prevention at the community level to some extend. After the campaign, the general population reported enhanced disease knowledge and awareness, albeit the effect's long-term viability was unknown. Future research should include evaluation of the understanding of the public in the intended mass public health messages of the health authorities.

Pharmacy students demonstrated the application of public health principles through the organisation of the public health campaign. This study further supports the incorporation of public health concepts in a pharmacy curriculum through experiential learning. Future studies could measure the learning outcomes of experiential learning and compare them to the traditional forms of learning in a pharmacy curriculum.

Our study had some limitations. As with other cross-sectional studies, we investigated a particular population; thus, the results may not be generalisable to other sites. Other factors could have influenced participants' replies in the pre-post survey, as they are exposed to different health experiences and exposure from other sources. Because of the short time interval between the pre- and post- surveys in this study, it is not possible to say whether the disease knowledge gained will be maintained after the campaign. Future studies could include a longer follow-up period to investigate the effects of community-based health campaigns in public health.

On the other hand, the added "feel good" impacts of project completion could have affected the pharmacy students' high post-event self-assessment scores. Future studies could include external or faculty assessment in assessing the impact of experiential learning in pharmacy curriculum.

\section{Acknowledgement}

Appreciation to the organising committee of the $18^{\text {th }}$ UCSI Public Health Campaign for accommodating the study sites.

\section{Ethical approval}


All procedures in this study were following the ethical standards of the Malaysian Ministry of Health Medical Research Ethics Committee, code number NMRR-19-1319-48612. Written informed consent was obtained from participants before the survey.

\section{REFERENCES}

Abdul-Razak, S., Daher, A.M., Ramli, A.S., Ariffin, F., Mazapuspavina, M.Y., Ambigga, K.S., Miskan, M., et al. (2016a), "Prevalence, awareness, treatment, control and socio demographic determinants of hypertension in Malaysian adults", BMC Public Health, BMC Public Health, Vol. 16 No. 1, pp. 1-10.

Abdul-Razak, S., Daher, A.M., Ramli, A.S., Ariffin, F., Mazapuspavina, M.Y., Ambigga, K.S., Miskan, M., et al. (2016b), "Prevalence, awareness, treatment, control and socio demographic determinants of hypertension in Malaysian adults", BMC Public Health, BMC Public Health, Vol. 16 No. 1, pp. 1-10.

Altman, R., Nunez De Ybarra, J. and Villablanca, A.C. (2014), “Community-based cardiovascular disease prevention to reduce cardiometabolic risk in latina women: A pilot program", Journal of Women's Health, Vol. 23 No. 4, pp. 350-357.

Bell, J., Dziekan, G., Pollack, C. and Mahachai, V. (2016), "Self-Care in the Twenty First Century: A Vital Role for the Pharmacist", Advances in Therapy, Springer Healthcare, Vol. 33 No. 10, pp. 1691-1703.

Bilal, M., Haseeb, A., Lashkerwala, S.S., Zahid, I., Siddiq, K., Saad, M., Dar, M.I., et al. (2015), "Knowledge, Awareness and Self-Care Practices of Hypertension Among Cardiac Hypertensive Patients", Global Journal of Health Science, Vol. 8 No. 2, pp. 9-19.

Charan, J. and Biswas, T. (2013), "How to calculate sample size for different study designs in medical research?”, Indian Journal of Psychological Medicine, Vol. 35 No. 2, pp. 121-126.

Cota, É., Ribeiro, L., Bezerra, J.S., Costa, A., da Silva, R.E. and Cota, G. (2017), “Using formal methods for content validation of medical procedure documents", International Journal of Medical Informatics, Elsevier B.V., Vol. 104, pp. 10-25.

Deepa, M., Bhansali, A., Anjana, R., Pradeepa, R., Joshi, S., Joshi, P., Dhandhania, V., et al. (2014), "Knowledge and awareness of diabetes in urban and rural India: The Indian Council of Medical Research India Diabetes Study (Phase I): Indian Council of Medical Research India Diabetes 4", Indian Journal of Endocrinology and Metabolism, Vol. 18 No. 3, pp. 379-385.

Duplaga, M. (2019), "Perception of the effectiveness of health-related campaigns among the adult population: An analysis of determinants", International Journal of Environmental Research and Public Health, Vol. 16 No. 5, available at:https://doi.org/10.3390/ijerph16050791.

Fjortoft, N. (2006), "Self-assessment in pharmacy education”, American Journal of Pharmaceutical Education, Vol. 70 No. 3, pp. 3-4.

Fryar, C.D., Ostchega, Y., Hales, C.M., Zhang, G. and Kruszon-Moran, D. (2017), "Hypertension Prevalence and Control Among Adults: United States, 2015-2016”, NCHS Data Brief, No. 289, pp. $1-8$. 
Health Development Agency. (2004), "The effectiveness of public health campaigns", Consumers and Markets, No. 7, pp. 1-5.

Institute for Public Health. (2019), "National Health and Morbidity Survey 2019 Non-communicable diseases, healthcare demand and health literacy”, Vol. 035 No. September, pp. 1-3.

Kibler, J.L., Ma, M., Hrzich, J. and Roas, R.A. (2018), "Public Knowledge of Cardiovascular Risk Numbers: Contextual Factors Affecting Knowledge and Health Behavior, and the Impact of Public Health Campaigns", Lifestyle in Heart Health and Disease, pp. 11-20.

Kolb, A.Y. and Kolb, D.A. (2017a), "Experiential Learning Theory as a Guide for Experiential Educators in Higher Education", ELTHE: A Journal for Engaged Educators, Vol. 1 No. 1, pp. 745.

Kolb, A.Y. and Kolb, D.A. (2017b), "Experiential Learning Theory as a Guide for Experiential Educators in Higher Education”, ELTHE: A Journal for Engaged Educators, Vol. 1 No. 1, pp. 745 .

Landy, D.C., Gorin, M.A., Rudock, R.J. and O’Connell, M.T. (2013), “Increasing access to cholesterol screening in rural communities catalyzes cardiovascular disease prevention", Journal of Rural Health, Vol. 29 No. 4, pp. 360-367.

Levin, B.L., Hanson, A. and Hurd, P.D. (Eds.). (2018), Introduction to Public Health in Pharmacy, Vol. 1, Oxford University Press, available at:https://doi.org/10.1093/med/9780190238308.001.0001.

Mahmud, K.A. (2015), “Knowledge of Diabetes Mellitus, Risk Factors and Complications Among the General Public in Kuala Lumpur”, Journal of Pharmaceutical Research, Vol. 4 No. 12, pp. 154170.

Minhat, H.S. and Hamedon, T.R. (2014), "Understanding Towards Diabetes Mellitus among Rural Adult Community in Malaysia”, World Journal of Medical Sciences, Vol. 11 No. 2, pp. 217-221.

Ministry of Health. (2004), Malaysian Burden of Disease and Injury Study: Health Prioritization : Burden of Disease Approach.

Ministry of Health Malaysia. (2018), Clinical Practice Guidelines: Management of Hypertension.

Morris, T.H. (2020), “Experiential learning-a systematic review and revision of Kolb's model”, Interactive Learning Environments, Taylor \& Francis, Vol. 28 No. 8, pp. 1064-1077.

Naing, C., Jun, Y.K., Yee, W.M., Waqiyuddin, S.B., Lui, L.C., Shaung, O.Y. and Haw, F.J. (2014a), "Willingness to take a screening test for colorectal cancer: A community-based survey in Malaysia”, European Journal of Cancer Prevention, Vol. 23 No. 2, pp. 71-75.

Naing, C., Jun, Y.K., Yee, W.M., Waqiyuddin, S.B., Lui, L.C., Shaung, O.Y. and Haw, F.J. (2014b), "Willingness to take a screening test for colorectal cancer: A community-based survey in Malaysia”, European Journal of Cancer Prevention, Vol. 23 No. 2, pp. 71-75.

National Institute of Health. (2017), Malaysian Burden of Disease and Injury Study 2009-2014, available at: http://iku.moh.gov.my/images/IKU/Document/REPORT/BOD/BOD2009-2014.pdf.

Owen, S., Professor Ieva Stupans, A. and Davey -Associate Investigator, A. (2008), "Experiential Placements in Pharmacy 'Quality Indicators for Best Practice Approaches to Experiential Placements in Pharmacy Programs' Final Report: March 2008 Steering Committee 
Membership", pp. 1-90.

Petrelli, F., Tiffi, F., Scuri, S., Nguyen, C.T.T. and Grappasonni, I. (2019), “The pharmacist's role in health information, vaccination and health promotion", Annali Di Igiene : Medicina Preventiva e Di Comunita, Vol. 31 No. 4, pp. 309-315.

Qamar, M., Iqubal, R.R.M., Ahmad, S., Shaikh, F.A. and Ismail, N.E. (2017), “Awareness of diabetes mellitus among general public in Shah Alam, Malaysia: A cross-sectional study”, Asian Journal of Pharmaceutical and Clinical Research, Vol. 10 No. 9, pp. 192-196.

Sathish Kumar, K., Singh, A.B. and Asem, P. (2015), "Prevalence, awareness, treatment and control of hypertension in urban communities of Imphal, Manipur", Journal of Interdisciplinary and Multidisciplinary Research, Vol. 2 No. 3, pp. 61-70.

Shima, R., Farizah, M.H. and Majid, H.A. (2014), “A qualitative study on hypertensive care behavior in primary health care settings in Malaysia", Patient Preference and Adherence, Vol. 8, pp. $1597-1609$.

Sinclair, D., Savage, E., O’ Brien, M., O’Reilly, A., Mullaney, C., Killeen, M., O’Reilly, O., et al. (2020), "Developing a national undergraduate standardized curriculum for future healthcare professionals on 'Making Every Contact Count' for chronic disease prevention in the Republic of Ireland.", Journal of Interprofessional Care, England, Vol. 34 No. 4, pp. 561-565.

Singh, H.K., Kennedy, G.A. and Stupans, I. (2020), "Pharmacist health coaching in Australian community pharmacies: What do pharmacy professionals think?", Health and Social Care in the Community, Vol. 28 No. 4, pp. 1190-1198.

Smith, R.E. and Olin, B.R. (2010), "Wellness: Pharmacy education’s role and responsibility.”, American Journal of Pharmaceutical Education, Vol. 74 No. 4, p. 69.

Strand, M.A., Mager, N.A.D., Hall, L., Martin, S.L. and Sarpong, D.F. (2020), "Pharmacy contributions to improved population health: Expanding the public health roundtable", Preventing Chronic Disease, Vol. 17, pp. 1-7.

Wheeler, J.S., McDonough, S.L.K. and Hagemann, T.M. (2017), “Assessing self-assessment practices: A survey of U.S. colleges and schools of pharmacy", Currents in Pharmacy Teaching and Learning, Elsevier, Vol. 9 No. 6, pp. 966-971.

Yen, S.T., Tan, A.K.G. and Mustapha, F.I. (2017), “Awareness of diabetes, hypertension, and hypercholesterolemia in Malaysia”, Journal of Diabetes, Vol. 9 No. 9, pp. 874-883.

Yeong, S.W. and Choong, Y.C. (2017), "Knowledge and characteristics of herbal supplement usage among community pharmacy customers in a Malaysian population”, Complementary Therapies in Medicine, Churchill Livingstone, Vol. 35, pp. 92-108.

Zamanzadeh, V., Ghahramanian, A., Rassouli, M., Abbaszadeh, A., Alavi-Majd, H. and Nikanfar, A.R. (2015), "Design and Implementation Content Validity Study: Development of an instrument for measuring Patient-Centered Communication”, Journal of Caring Sciences, Vol. 4 No. 2, pp. 165-178. 
Table I. Characteristics of participants

\begin{tabular}{ll}
\hline Participant characteristics & n (\%) \\
& $(\mathrm{N}=22$
\end{tabular}

Gender

Male

$90(40.9)$

Female

$130(59.1)$

Age range (year-old)

18-30

68 (30.9)

31-50

83 (37.7)

$51-70$

57 (25.9)

$>70$

$12(5.5)$

Ethnicity

Chinese

$132(60.0)$

Malay

84 (38.2)

Indians

$2(0.9)$

Others

$2(0.9)$

Education level

Primary education

$3(1.4)$

Secondary or high school education

109 (49.5)

College or university

107 (48.6)

No formal education

$1(0.5)$

Household income (monthly)

$$
\begin{array}{ll}
<\text { RM1000 } & 37(16.8) \\
\text { RM1000 - RM3000 } & 95(43.2) \\
\text { RM3001 - RM5000 } & 72(32.7) \\
>\text { RM5000 } & 16(7.3)
\end{array}
$$

Marital Status

Single

78 (35.5)

Married

$142(64.5)$

Random blood pressure (SBP/DBP) (mmHg)

$$
\begin{array}{ll}
<120 / 80 & 78(35.5) \\
120-129 \text { either or } 80-84 & 45(20.5) \\
130-139 \text { either or } 85 \text { to } 89 & 32(14.5) \\
140-159 \text { either or } 90 \text { to } 99 & 48(21.8) \\
160-179 \text { either or } 100 \text { to } 109 & 16(7.2) \\
\geq 180 / 110 & 1(0.5)
\end{array}
$$

Random blood glusoce ( $\mathrm{mmol} / \mathrm{L})$

$$
<7.8
$$




$\begin{array}{ll}7.8-11 & 13(6.5) \\ \geq 11.1 & 11(5.5) \\ * \text { Not measured } & 20 \text { (NA) }\end{array}$

Self-awareness of own blood pressure readings

$\begin{array}{ll}\text { Yes } & 43(19.55) \\ \text { No } & 172(78.18) \\ \text { Not sure } & 5(2.27)\end{array}$

Self-awareness of own blood glucose readings

$\begin{array}{ll}\text { Yes } & 16(7.27) \\ \text { No } & 194(88.18) \\ \text { Not sure } & 10(4.55)\end{array}$

SBP: systolic blood pressure; DBP: diastolic blood pressure *measurement was not taken as no fasting 2 hours before test NA: not applicable (data were not included in statistics) 
Table II. Knowledge of participants on hypertension before and after a community-based health campaign

\section{Pre-Campaign}

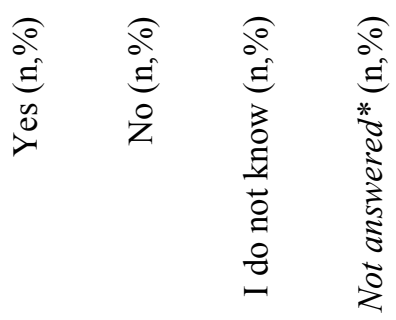

\section{Post-Campaign}

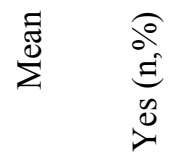

Wilcoxon-signed rank

What are the signs and symptoms of high blood pressure?
a. Headache
$\begin{array}{ccc}153, & 40, & 22 \\ 69.5 & 18.2 & 10 .\end{array}$
$\begin{array}{ll}5, & 1.39\end{array}$
$\begin{array}{ll}190, & 20, \\ 86.4 & 9.1\end{array}$
8,
3.6
2,
0.9
1.17
-5.176
$p<0.00$
$-0.355$
b. Dizziness
$\begin{array}{cccc}173, & 21, & 22, & 4, \\ 78.6 & 9.5 & 10.0 & 1.8\end{array}$
1.30
197, $15, \quad 8$,
0,
0.0
$\begin{array}{cc}1.14 & -4.051 \\ \mathrm{p} & <0.001\end{array}$
c. Fatigue
132, 55, 29, 4
1.54
176, 32, $\quad 11$,
1
1.25
$-5.793$
$\mathrm{p}<0.001$

Which of the following lifestyle can lower blood pressure?

\begin{tabular}{|c|c|c|c|c|c|c|c|c|c|c|c|c|}
\hline a. High salt intake & $\begin{array}{c}6 \\
2.7\end{array}$ & $\begin{array}{l}183 \\
83.2\end{array}$ & $\begin{array}{c}28 \\
12.7\end{array}$ & $\begin{array}{l}3 \\
1.4\end{array}$ & 2.10 & $\begin{array}{c}2 \\
0.9\end{array}$ & $\begin{array}{l}213 \\
96.8\end{array}$ & $\begin{array}{c}2 \\
0.9\end{array}$ & $\begin{array}{l}3 \\
1.4\end{array}$ & 2.00 & $\begin{array}{c}-4.017 \\
\mathrm{p}<0.001\end{array}$ & -0.274 \\
\hline $\begin{array}{l}\text { b. Alcohol } \\
\text { consumption }\end{array}$ & $\begin{array}{c}5 \\
2.3\end{array}$ & $\begin{array}{l}175 \\
79.5\end{array}$ & $\begin{array}{c}35 \\
15.9\end{array}$ & $\begin{array}{c}5 \\
2.3\end{array}$ & 2.14 & $\begin{array}{l}3, \\
1.4\end{array}$ & $\begin{array}{l}191 \\
86.8\end{array}$ & $\begin{array}{c}23 \\
10.5\end{array}$ & $\begin{array}{l}3 \\
1.4\end{array}$ & 2.09 & $\begin{array}{c}-2.84 \\
\mathrm{p}<0.05\end{array}$ & -0.195 \\
\hline $\begin{array}{l}\text { c. Regular physical } \\
\text { activity }\end{array}$ & $\begin{array}{l}212 \\
96.4\end{array}$ & $\begin{array}{c}5, \\
2.3\end{array}$ & $\begin{array}{l}2 \\
0.9\end{array}$ & $\begin{array}{l}1 \\
0.5\end{array}$ & 1.04 & $\begin{array}{l}215 \\
97.7\end{array}$ & $\begin{array}{l}4, \\
1.8\end{array}$ & $\begin{array}{c}0 \\
0.0\end{array}$ & $\begin{array}{c}1 \\
0.5\end{array}$ & 1.02 & $\begin{array}{c}-1.518 \\
p=0.129\end{array}$ & -0.103 \\
\hline d. Healthy eating & $\begin{array}{l}216 \\
98.2\end{array}$ & $\begin{array}{c}1 \\
0.5\end{array}$ & $\begin{array}{c}1 \\
0.5\end{array}$ & $\begin{array}{l}2, \\
1.0\end{array}$ & 1.01 & $\begin{array}{l}217 \\
98.6\end{array}$ & $\begin{array}{c}2 \\
0.9\end{array}$ & $\begin{array}{l}0, \\
0.0\end{array}$ & $\begin{array}{l}1 \\
0.5\end{array}$ & 1.01 & $\begin{array}{c}-0.447 \\
p=0.655\end{array}$ & -0.030 \\
\hline e. Smoking & $\begin{array}{l}9, \\
4.1\end{array}$ & $\begin{array}{l}204 \\
92.7\end{array}$ & $\begin{array}{l}4 \\
1.8\end{array}$ & $\begin{array}{l}3, \\
1.4\end{array}$ & 1.98 & $\begin{array}{l}4, \\
1.8\end{array}$ & $\begin{array}{l}213, \\
96.8\end{array}$ & $\begin{array}{c}0 \\
0.0\end{array}$ & $\begin{array}{l}3, \\
1.4\end{array}$ & 1.98 & $\begin{array}{c}-0.302 \\
p=0.763\end{array}$ & -0.021 \\
\hline f. Stress & $\begin{array}{l}9, \\
4.1\end{array}$ & $\begin{array}{l}196, \\
89.1\end{array}$ & $\begin{array}{l}12, \\
5.5\end{array}$ & $\begin{array}{l}3, \\
1.4\end{array}$ & 2.01 & $\begin{array}{c}5, \\
2.3\end{array}$ & $\begin{array}{l}209, \\
95.0\end{array}$ & $\begin{array}{l}3, \\
1.4\end{array}$ & $\begin{array}{l}3, \\
1.4\end{array}$ & 1.99 & $\begin{array}{c}-1.213 \\
\mathrm{p}=0.225\end{array}$ & -0.083 \\
\hline $\begin{array}{l}\text { g. Increased } \\
\text { potassium intake }\end{array}$ & $\begin{array}{l}37 \\
16.8\end{array}$ & $\begin{array}{c}80 \\
36.4\end{array}$ & $\begin{array}{l}96, \\
43.6\end{array}$ & $\begin{array}{l}7, \\
3.2\end{array}$ & 2.28 & $\begin{array}{l}77, \\
35.0\end{array}$ & $\begin{array}{l}71 \\
32.3\end{array}$ & $\begin{array}{c}68 \\
30.9\end{array}$ & $\begin{array}{l}4, \\
1.8\end{array}$ & 1.96 & $\begin{array}{c}-5.798 \\
p<0.001\end{array}$ & -0.4 \\
\hline
\end{tabular}

Q5 What are the risk factors of high blood pressure?

8

a. Family history of hypertension

b. Increased age
$183, \quad 24, \quad 7, \quad 6$ $\begin{array}{llll}83.2 & 10.9 & 3.2 & 2.7\end{array}$

$169, \quad 40, \quad 4, \quad 7$,
6

$\begin{array}{ll}76.8 & 18.2-1.8\end{array}$

93.2

198, $\quad 18, \quad 2, \quad 2$,

$\begin{array}{llll}190.0 & 8.2 & 0.9 & 1.0\end{array}$

3

$1.07 \quad-2.997$

$\mathrm{p}=0.003$ 
2

4

c. Overweight

$174, \quad 35, \quad 5$,

$\begin{array}{lll}79.1 & 15.9 & 2.3\end{array}$

6

1.21

205, 11

$1, \quad 2, \quad 2$,

$1.07 \quad-5.231$

$-0.359$

d. High salt intake

$189, \quad 3, \quad 22$

$6, \quad 1.22 \quad 212$

5.25

0.9

1.0

$\mathrm{p}<0.001$

$-0.295$

e. Salt intake of more

than one teaspoon per

$\begin{array}{lll}85.9 & 1.4 & 10.0\end{array}$

212,
96.4

1,
0.5

5

2,

1.05

$-4.300$

$<0.001$

$-0.295$ day

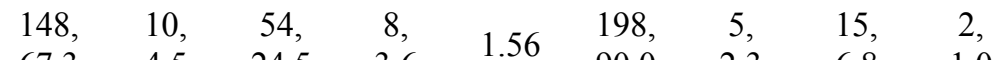

$1.16-6.227$

$-0.429$

\begin{tabular}{|c|c|c|c|c|c|c|c|c|c|c|c|c|}
\hline a. Heart failure & $\begin{array}{l}201, \\
91.4\end{array}$ & $\begin{array}{c}6, \\
2.7\end{array}$ & $\begin{array}{c}6, \\
2.7\end{array}$ & $\begin{array}{c}7, \\
3.2\end{array}$ & 1.08 & $\begin{array}{l}213, \\
96.8\end{array}$ & $\begin{array}{c}2, \\
0.9\end{array}$ & $\begin{array}{c}1, \\
0.5\end{array}$ & $\begin{array}{l}4, \\
1.9\end{array}$ & 1.02 & $\begin{array}{c}-2.739 \\
p=0.006\end{array}$ & -0.189 \\
\hline b. Stroke & $\begin{array}{l}203, \\
92.3\end{array}$ & $\begin{array}{c}6 \\
2.7\end{array}$ & $\begin{array}{l}4, \\
1.8\end{array}$ & $\begin{array}{c}7, \\
3.2\end{array}$ & 1.07 & $\begin{array}{l}216, \\
98.2\end{array}$ & $\begin{array}{c}2, \\
0.9\end{array}$ & $\begin{array}{c}1, \\
0.5\end{array}$ & $\begin{array}{c}1, \\
0.5\end{array}$ & 1.02 & $\begin{array}{c}-2.428 \\
p=0.015\end{array}$ & -0.166 \\
\hline c. Kidney disease & $\begin{array}{l}136 \\
61.8\end{array}$ & $\begin{array}{l}39 \\
17.7\end{array}$ & $\begin{array}{c}38, \\
17.3\end{array}$ & $\begin{array}{c}7, \\
3.2\end{array}$ & 1.54 & $\begin{array}{l}196, \\
89.1\end{array}$ & $\begin{array}{l}15, \\
6.8\end{array}$ & $\begin{array}{c}6, \\
2.7\end{array}$ & $\begin{array}{l}3, \\
1.4\end{array}$ & 1.12 & $\begin{array}{c}-6.903 \\
p<0.001\end{array}$ & -0.475 \\
\hline d. Impaired vision & $\begin{array}{l}125, \\
56.8\end{array}$ & $\begin{array}{c}38, \\
17.3\end{array}$ & $\begin{array}{c}49, \\
22.3\end{array}$ & & 1.64 & $\begin{array}{l}190, \\
86.4\end{array}$ & $\begin{array}{l}17, \\
7.7\end{array}$ & $\begin{array}{l}11, \\
5.0\end{array}$ & $\begin{array}{c}2, \\
0.9\end{array}$ & 1.18 & $\begin{array}{c}-7.219 \\
p<0.001\end{array}$ & -0.497 \\
\hline e. Cancer & $\begin{array}{c}52, \\
23.6\end{array}$ & $\begin{array}{l}122, \\
55.5\end{array}$ & $\begin{array}{c}37, \\
16.8\end{array}$ & $\begin{array}{c}9, \\
4.1\end{array}$ & 1.93 & $\begin{array}{l}45, \\
20.5\end{array}$ & $\begin{array}{l}160, \\
72.7\end{array}$ & $\begin{array}{l}13, \\
5.9\end{array}$ & $\begin{array}{c}2, \\
0.9\end{array}$ & 1.85 & $\begin{array}{c}-2.256 \\
p=0.024\end{array}$ & -0.156 \\
\hline f. Diabetes & $\begin{array}{l}124, \\
56.4\end{array}$ & $\begin{array}{c}60, \\
27.3\end{array}$ & $\begin{array}{c}27, \\
12.3\end{array}$ & $\begin{array}{l}9, \\
4.1\end{array}$ & 1.54 & $\begin{array}{c}85 \\
38.6\end{array}$ & $\begin{array}{l}128, \\
58.2\end{array}$ & $\begin{array}{c}5, \\
2.3\end{array}$ & $\begin{array}{c}2, \\
0.9\end{array}$ & 1.63 & $\begin{array}{c}-1.980 \\
p=0.048\end{array}$ & -0.137 \\
\hline
\end{tabular}

*question was not answered by participants 
Table III. Knowledge of participants on diabetes before and after attending a health campaign

$$
\text { Pre-Campaign }
$$

Post-Campaign

Wilcoxon-signed

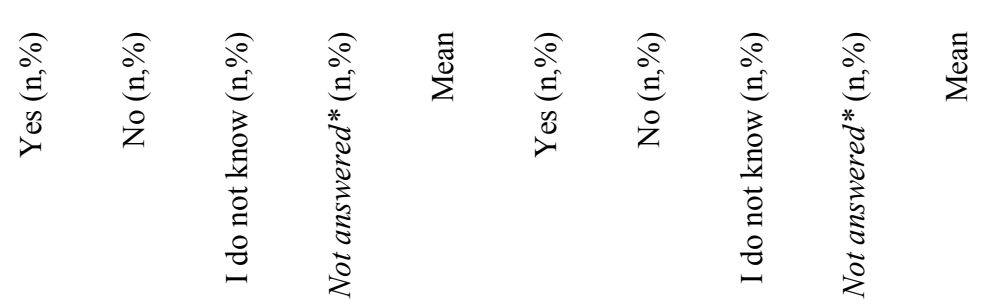

\begin{tabular}{|c|c|c|c|c|c|c|c|c|c|c|c|c|}
\hline a. Increased thirst & $\begin{array}{l}102 \\
46.4\end{array}$ & $\begin{array}{c}35 \\
15.9\end{array}$ & $\begin{array}{c}62 \\
28.2\end{array}$ & $\begin{array}{l}21, \\
9.5\end{array}$ & 1.80 & $\begin{array}{l}173 \\
78.6\end{array}$ & $\begin{array}{l}12 \\
5.5\end{array}$ & $\begin{array}{l}31 \\
14.1\end{array}$ & $\begin{array}{l}4, \\
1.8\end{array}$ & 1.34 & $\begin{array}{c}-7.258 \\
p<0.001\end{array}$ & -0.517 \\
\hline b. Increased hunger & $\begin{array}{c}78 \\
35.5\end{array}$ & $\begin{array}{l}59 \\
26.8\end{array}$ & $\begin{array}{c}63 \\
28.6\end{array}$ & $\begin{array}{l}20 \\
9.1\end{array}$ & 1.93 & $\begin{array}{l}163 \\
74.1\end{array}$ & $\begin{array}{l}20 \\
9.1\end{array}$ & $\begin{array}{l}34, \\
15.5\end{array}$ & $\begin{array}{l}3, \\
1.4\end{array}$ & 1.41 & $\begin{array}{c}-8.022 \\
\mathrm{p}<0.001\end{array}$ & -0.569 \\
\hline c. Frequent urination & $\begin{array}{l}151 \\
68.6\end{array}$ & $\begin{array}{l}17 \\
7.7\end{array}$ & $\begin{array}{l}32 \\
14.5\end{array}$ & $\begin{array}{l}20, \\
9.1\end{array}$ & 1.41 & $\begin{array}{l}193 \\
87.7\end{array}$ & $\begin{array}{l}8, \\
3.6\end{array}$ & $\begin{array}{l}16, \\
7.3\end{array}$ & $\begin{array}{l}3, \\
1.4\end{array}$ & 1.18 & $\begin{array}{c}-4.642 \\
\mathrm{p}<0.001\end{array}$ & -0.329 \\
\hline $\begin{array}{l}\text { d. Frequent night time } \\
\text { urination }\end{array}$ & $\begin{array}{l}155 \\
70.5\end{array}$ & $\begin{array}{l}13 \\
5.9\end{array}$ & $\begin{array}{l}31 \\
14.1\end{array}$ & $\begin{array}{l}21, \\
9.5\end{array}$ & 1.38 & $\begin{array}{l}195 \\
88.6\end{array}$ & $\begin{array}{l}5, \\
2.3\end{array}$ & $\begin{array}{l}16, \\
7.3\end{array}$ & $\begin{array}{l}4, \\
1.8\end{array}$ & 1.17 & $\begin{array}{c}-4.512 \\
\mathrm{p}<0.001\end{array}$ & -0.321 \\
\hline e. Fatigue & $\begin{array}{l}130 \\
59.1\end{array}$ & $\begin{array}{l}44, \\
20.0\end{array}$ & $\begin{array}{l}26, \\
11.8\end{array}$ & $\begin{array}{l}20, \\
9.1\end{array}$ & 1.48 & $\begin{array}{l}188 \\
85.5\end{array}$ & $\begin{array}{l}20, \\
9.1\end{array}$ & $\begin{array}{l}10, \\
4.5\end{array}$ & $\begin{array}{l}2 \\
0.9\end{array}$ & 1.18 & $\begin{array}{c}-5.928 \\
p<0.001\end{array}$ & -0.419 \\
\hline f. Weight loss & $\begin{array}{l}82 \\
37.3\end{array}$ & $\begin{array}{l}82 \\
37.3\end{array}$ & $\begin{array}{l}36 \\
16.4\end{array}$ & $\begin{array}{l}20 \\
9.1\end{array}$ & & $\begin{array}{l}158 \\
71.8\end{array}$ & $\begin{array}{l}43 \\
19.5\end{array}$ & $\begin{array}{l}15, \\
6.8\end{array}$ & $\begin{array}{l}4, \\
1.8\end{array}$ & 1.34 & $\begin{array}{c}-7.817 \\
p<0.001\end{array}$ & -0.556 \\
\hline g. Altered vision & $\begin{array}{l}139 \\
63.2\end{array}$ & $\begin{array}{l}26, \\
11.8\end{array}$ & $\begin{array}{c}35, \\
15.9\end{array}$ & $\begin{array}{l}20, \\
9.1\end{array}$ & & $\begin{array}{l}197, \\
89.5\end{array}$ & $\begin{array}{c}8, \\
3.6\end{array}$ & $\begin{array}{l}13, \\
5.9\end{array}$ & $\begin{array}{l}2, \\
0.9\end{array}$ & 1.16 & $\begin{array}{c}-5.684 \\
p<0.001\end{array}$ & -0.402 \\
\hline
\end{tabular}

Q7 What are the signs and symptoms of high blood glucose?

\begin{tabular}{|c|c|c|c|c|c|c|c|c|c|c|c|c|}
\hline a. Smoking & $\begin{array}{l}198, \\
90.0\end{array}$ & $\begin{array}{c}2 \\
0.9\end{array}$ & $\begin{array}{c}0, \\
0.0\end{array}$ & $\begin{array}{l}20, \\
9.1\end{array}$ & 1.99 & $\begin{array}{l}216, \\
98.2\end{array}$ & $\begin{array}{c}1, \\
0.5\end{array}$ & $\begin{array}{c}0, \\
0.0\end{array}$ & $\begin{array}{l}3, \\
1.4\end{array}$ & 2.00 & $\begin{array}{c}-1.414 \\
\mathrm{p}=0.157\end{array}$ & -0.1 \\
\hline b. Alcohol consumption & $\begin{array}{l}3 \\
1.4\end{array}$ & $\begin{array}{l}196, \\
89.1\end{array}$ & $\begin{array}{l}1, \\
0.5\end{array}$ & $\begin{array}{l}20 \\
9.1\end{array}$ & 1.99 & $\begin{array}{c}1, \\
0.5\end{array}$ & $\begin{array}{l}216, \\
98.2\end{array}$ & $\begin{array}{c}0, \\
0.0\end{array}$ & $\begin{array}{l}3, \\
1.4\end{array}$ & 2.00 & $\begin{array}{c}-1.000 \\
p=0.317\end{array}$ & -0.071 \\
\hline c. Healthy diet & $\begin{array}{l}197 \\
89.5\end{array}$ & $\begin{array}{l}3 \\
1.4\end{array}$ & $\begin{array}{l}1, \\
0.5\end{array}$ & $\begin{array}{l}19, \\
8.6\end{array}$ & 1.03 & $\begin{array}{l}217, \\
98.6\end{array}$ & $\begin{array}{c}1, \\
0.5\end{array}$ & $\begin{array}{c}0, \\
0.0\end{array}$ & $\begin{array}{c}2, \\
0.9\end{array}$ & 1.01 & $\begin{array}{c}-1.633 \\
p=0.102\end{array}$ & -0.115 \\
\hline $\begin{array}{l}\text { d. Regular physical } \\
\text { exercise }\end{array}$ & $\begin{array}{l}199 \\
90.5\end{array}$ & $\begin{array}{c}2, \\
0.9\end{array}$ & $\begin{array}{c}0, \\
0.0\end{array}$ & $\begin{array}{l}19, \\
8.6\end{array}$ & 1.01 & $\begin{array}{l}217, \\
98.6\end{array}$ & $\begin{array}{l}1, \\
0.5\end{array}$ & $\begin{array}{c}0, \\
0.0\end{array}$ & $\begin{array}{c}2, \\
0.9\end{array}$ & 1.01 & $\begin{array}{c}-1.000 \\
\mathrm{p}=0.317\end{array}$ & 0.071 \\
\hline
\end{tabular}

Q8 Which of the following lifestyle can lower blood glucose?

\begin{tabular}{|c|c|c|c|c|c|c|c|c|c|c|c|c|}
\hline $\begin{array}{l}\text { a. Family history of } \\
\text { hypertension }\end{array}$ & $\begin{array}{l}138, \\
62.7\end{array}$ & $\begin{array}{c}51 \\
23.2\end{array}$ & $\begin{array}{c}9 \\
4.1\end{array}$ & $\begin{array}{c}22 \\
10.0\end{array}$ & 1.35 & $\begin{array}{l}133 \\
60.5\end{array}$ & $\begin{array}{c}77 \\
35.0\end{array}$ & $\begin{array}{c}7, \\
3.2\end{array}$ & $\begin{array}{l}3 \\
1.4\end{array}$ & 1.42 & $\begin{array}{c}-1.303 \\
p=0.193\end{array}$ & -0.093 \\
\hline b. Increased age & $\begin{array}{l}147, \\
66.8\end{array}$ & $\begin{array}{c}49 \\
22.3\end{array}$ & $\begin{array}{l}3 \\
1.4\end{array}$ & $\begin{array}{l}21 \\
9.5\end{array}$ & 1.28 & $\begin{array}{l}197 \\
89.5\end{array}$ & $\begin{array}{l}17 \\
7.7\end{array}$ & $\begin{array}{l}3 \\
1.4\end{array}$ & $\begin{array}{l}3 \\
1.4\end{array}$ & 1.11 & $\begin{array}{c}-5.324 \\
\mathrm{p}<0.001\end{array}$ & -0.378 \\
\hline c. Overweight & $\begin{array}{l}167, \\
75.9\end{array}$ & $\begin{array}{l}27 \\
12.3\end{array}$ & $\begin{array}{c}3, \\
1.4\end{array}$ & $\begin{array}{c}23 \\
10.5\end{array}$ & 1.17 & $\begin{array}{l}205, \\
93.2\end{array}$ & $\begin{array}{l}12, \\
5.5\end{array}$ & $\begin{array}{c}0, \\
0.0\end{array}$ & $\begin{array}{c}3 \\
1.4\end{array}$ & 1.06 & $\begin{array}{c}-4.669 \\
p<0.001\end{array}$ & -0.334 \\
\hline
\end{tabular}

Q9 What are the risk factors of high blood glucose? 


\begin{tabular}{|c|c|c|c|c|c|c|c|c|c|c|c|}
\hline d. Physical inactivity & $\begin{array}{l}193, \\
87.7\end{array}$ & $\begin{array}{l}3, \\
1.4\end{array}$ & $\begin{array}{c}1, \\
0.5\end{array}$ & $\begin{array}{c}23 \\
10.5\end{array}$ & 1.03 & $\begin{array}{l}213 \\
96.8\end{array}$ & $\begin{array}{c}4, \\
1.8\end{array}$ & $\begin{array}{c}0, \\
0.0\end{array}$ & $\begin{array}{l}3, \\
1.4\end{array}$ & 1.02 & $\begin{array}{c}-1.000 \\
p=0.317\end{array}$ \\
\hline e. High blood pressure & $\begin{array}{l}147, \\
66.8\end{array}$ & $\begin{array}{c}33, \\
15.0\end{array}$ & $\begin{array}{l}16, \\
7.3\end{array}$ & $\begin{array}{c}24, \\
10.9\end{array}$ & 1.33 & $\begin{array}{l}189 \\
85.9\end{array}$ & $\begin{array}{l}19, \\
8.6\end{array}$ & $\begin{array}{l}9, \\
4.1\end{array}$ & $\begin{array}{l}3, \\
1.4\end{array}$ & 1.17 & $\begin{array}{c}-4.338 \\
\mathrm{p}<0.001\end{array}$ \\
\hline
\end{tabular}

Q10 High blood glucose can cause which of the following conditions?

\begin{tabular}{|c|c|c|c|c|c|c|c|c|c|c|c|c|}
\hline a. Impaired vision & $\begin{array}{l}142, \\
64.5\end{array}$ & $\begin{array}{c}31, \\
14.1\end{array}$ & $\begin{array}{c}25, \\
11.4\end{array}$ & $\begin{array}{c}22, \\
10.0\end{array}$ & 1.41 & $\begin{array}{l}203, \\
92.3\end{array}$ & $\begin{array}{c}5, \\
2.3\end{array}$ & $\begin{array}{c}9, \\
4.1\end{array}$ & $\begin{array}{c}3, \\
1.4\end{array}$ & 1.11 & $\begin{array}{c}-6.049 \\
p<0.001\end{array}$ & -0.431 \\
\hline b. Kidney disease & $\begin{array}{l}166, \\
75.5\end{array}$ & $\begin{array}{l}15, \\
6.8\end{array}$ & $\begin{array}{l}17 \\
7.7\end{array}$ & $\begin{array}{c}22, \\
10.0\end{array}$ & 1.25 & $\begin{array}{l}208, \\
94.5\end{array}$ & $\begin{array}{c}5, \\
2.3\end{array}$ & $\begin{array}{c}4, \\
1.8\end{array}$ & $\begin{array}{c}3, \\
1.4\end{array}$ & 1.06 & $\begin{array}{c}-4.327 \\
p<0.001\end{array}$ & -0.308 \\
\hline c. Peripheral neuropathy & $\begin{array}{c}99 \\
45.0\end{array}$ & $\begin{array}{l}20, \\
9.1\end{array}$ & $\begin{array}{c}77, \\
35.0\end{array}$ & $\begin{array}{c}24, \\
10.9\end{array}$ & 1.89 & $\begin{array}{l}173, \\
78.6\end{array}$ & $\begin{array}{c}8, \\
3.6\end{array}$ & $\begin{array}{c}36, \\
16.4\end{array}$ & $\begin{array}{c}3, \\
1.4\end{array}$ & 1.37 & $\begin{array}{c}-7.674 \\
p<0.001\end{array}$ & -0.55 \\
\hline d. Coronary heart disease & $\begin{array}{l}117, \\
53.2\end{array}$ & $\begin{array}{c}28, \\
12.7\end{array}$ & $\begin{array}{c}52, \\
23.6\end{array}$ & $\begin{array}{c}23, \\
10.5\end{array}$ & 1.67 & $\begin{array}{l}184, \\
83.6\end{array}$ & $\begin{array}{l}10, \\
4.5\end{array}$ & $\begin{array}{c}24, \\
10.9\end{array}$ & $\begin{array}{c}2, \\
0.9\end{array}$ & 1.27 & $\begin{array}{c}-6.964 \\
\mathrm{p}<0.001\end{array}$ & -0.496 \\
\hline e. Stroke & $\begin{array}{l}133 \\
60.5\end{array}$ & $\begin{array}{c}30, \\
13.6\end{array}$ & $\begin{array}{c}34 \\
15.5\end{array}$ & $\begin{array}{c}23, \\
10.5\end{array}$ & 1.50 & $\begin{array}{l}186, \\
84.5\end{array}$ & $\begin{array}{l}13, \\
5.9\end{array}$ & $\begin{array}{l}18, \\
8.2\end{array}$ & $\begin{array}{c}3, \\
1.4\end{array}$ & 1.23 & $\begin{array}{c}-5.989 \\
p<0.001\end{array}$ & -0.428 \\
\hline f. Diabetic foot & $\begin{array}{l}187, \\
85.0\end{array}$ & $\begin{array}{l}4, \\
1.8\end{array}$ & $\begin{array}{l}7, \\
3.2\end{array}$ & $\begin{array}{c}22, \\
10.0\end{array}$ & 1.09 & $\begin{array}{l}212, \\
96.4\end{array}$ & $\begin{array}{c}2, \\
0.9\end{array}$ & $\begin{array}{c}3, \\
1.4\end{array}$ & $\begin{array}{c}3, \\
1.4\end{array}$ & 1.04 & $\begin{array}{c}-2.271 \\
p=0.023\end{array}$ & -0.162 \\
\hline g. Sexual dysfunction & $\begin{array}{c}87, \\
39.5\end{array}$ & $\begin{array}{c}58, \\
26.4\end{array}$ & $\begin{array}{c}53 \\
24.1\end{array}$ & $\begin{array}{c}22, \\
10.0\end{array}$ & 1.83 & $\begin{array}{l}154, \\
70.0\end{array}$ & $\begin{array}{c}33, \\
15.0\end{array}$ & $\begin{array}{c}30, \\
13.6\end{array}$ & $\begin{array}{c}3, \\
1.4\end{array}$ & 1.43 & $\begin{array}{c}-6.778 \\
p<0.001\end{array}$ & -0.483 \\
\hline h. Depression & $\begin{array}{c}55, \\
25.0\end{array}$ & $\begin{array}{l}111, \\
50.5\end{array}$ & $\begin{array}{c}31, \\
14.1\end{array}$ & $\begin{array}{c}23, \\
10.5\end{array}$ & 1.88 & $\begin{array}{l}119, \\
54.1\end{array}$ & $\begin{array}{c}78, \\
35.5\end{array}$ & $\begin{array}{l}19, \\
8.6\end{array}$ & $\begin{array}{l}4, \\
1.8\end{array}$ & 1.54 & $\begin{array}{c}-6.461 \\
p<0.001\end{array}$ & -0.463 \\
\hline i. Cancer & $\begin{array}{c}45, \\
20.5\end{array}$ & $\begin{array}{l}121, \\
55.0\end{array}$ & $\begin{array}{l}31, \\
14.1\end{array}$ & $\begin{array}{l}23, \\
10.5\end{array}$ & 1.93 & $\begin{array}{c}35, \\
15.9\end{array}$ & $\begin{array}{l}163, \\
74.1\end{array}$ & $\begin{array}{l}17 \\
7.7\end{array}$ & $\begin{array}{c}5, \\
2.3\end{array}$ & 1.92 & $\begin{array}{c}-0.146 \\
\mathrm{p}=0.884\end{array}$ & -0.01 \\
\hline
\end{tabular}

*question was not answered by participants 